\title{
The Effectiveness of Teaching Writing Descriptive Text by Using Social Media "Instagram" to Improve Students' Writing Ability at Junior High School Students
}

\author{
Warda, Encik Gaviani \\ Teacher of Kindergarten in Hang Tuah 18 Surabaya, Indonesia \\ encikgaviani@gmail.com
}

Wijaya, Armeria

Lecture English Department Faculty of Education and Teacher Training

Muhammadiyah University of Surabaya, Indonesia

\section{Article History}

Received: 1March 2019

Reviewed:2 March 2019

Accepted: 30 April 2019

\begin{abstract}
Teaching writing is one skill that is taught by English teacher in school. It became important skill that student have to master writing skill. The researcher chooses Descriptive Text, because it is one of type text to describe something such as place, animal, people and things. The researcher use social media of "Instagram" to teach student in writing descriptive text to improve students writing ability. The researcher use experimental research in quantitative method which two classes as experimental and control group. The sample of the data is taken from Barunawati Junior High School students. The researcher use snowball sampling. The result has been calculated by using SPSS 20.0. The result showed that teaching writing descriptive text using social media“Instagram" to improve students writing ability is effective.
\end{abstract}

Keywords: Writing, Instagram and Descriptive Text.

\section{Introduction}

Nowadays, technology is more sophisticated and modern. There are many types of new technology which is one of them is smartphone. In this era most of people using smartphone like their soul mate. They cannot separate with their own smartphone. People are very addicted with it and they use it for anything. In addition, it has many features for them and all of people from child until old can access it. Furthermore, children can access any website without any guidance from parents. Most of people have own smartphone because they need to access their social media.

Social media is one thing which is people not only teenagers love it but also children and old people. According to Taprial (2012:8) social media is the media that permitted be social or get social by sharing with each other such as, content, news, photo, etc. The use of social media is different from one to another. Some people use it for business, shopping, marketing also learning. Since, social media become glow most of people take the benefit to get social more wide as like Taprial said before. Instagram is one kind of social media that used by people to chat or share their moments such as photo or video. Users of "Instagram" are become increasing than before. According to Goenawan (2015) who adopted in Business Insider that until now "Instagram" users reach until 150 million so it make "Instagram" become the biggest social network no. $14^{\text {th }}$ in the world. 
Warda \& Armeria, Tell : The Effectiveness of Teaching Writing... Vol.7, No.1, 16-24, April 2019

Doi: http://dx.doi.org/10.30651/tell.v7i1.2696

Furthermore, more than $90 \%$ users are people who under 35 years old and $68 \%$ users who are from among woman. In addition, there are some reviews from user who used "Intagram" from Google play such, "Thank You", "Instagram is interresting", "Colorful", etc.

People become creative to use it for anything which one teacher can use social media as learning media as new innovation. People should be smart to face it, in order to use it wisely. From child until adult has social media to help them communicate easily. Social media is a media that is used to socialize with each other by online. They have social media not only use it for chatting but also most of people use it for business and some of them use social media for teaching learning.

English is one of the subjects that are taught in junior high school. There are four skills which people have to learn and mastered in learning English such as, writing, speaking, listening and reading. It is important for students to learn and understand the whole skills because all of those are connected in learning English. Every student has different of difficulties when learned English in school. One of them is writing.

Writing is one of the most important skills in learning English. In addition, student should deliver their idea into paper also with good structure and grammar. Therefore, students admit that writing is difficult. Teacher need to change how they teach become creative and fun, so it makes them happy when learned it.

According to Rao (2014) students more improve their comprehension skills after reading newspaper, magazines, journal, articles and other printed materials provided by teacher.

Therefore there are many teachers use media as teaching aids based on the subject matter. Rao (2014) added that teachers believe print media also help students in developing reading and writing ability by attachment the text books. Moreover teachers who teach foreign language also have media to help them, so it make easy to teacher and students. By using media, it make English language teaching more effective and better and can help students to understand and experiment with the language. To conclude, teaching using media can help teacher easy to teach and make student become interest and understand to learn English.

According to Parker and Boyd (2010:15) educators or teachers have a big role in helping to facilitate the culture transition taking place as public and private aspects of lives among teenagers enter a public culture that is networked and mediated. Teachers have an important role in digital era because many development of technology that can help teacher as teaching aid as new media for learning. Nowadays, there are many types of social media that used by people from child until old. One kind of social media that addicted by people is "Instagram". Actually, people can face it wisely people can utilize phenomena of social media. Social media "Instagram" as teaching media aid can be used in writing class.

Using "Instagram" as leaning media is an easy way to help students learn about descriptive text. "Instagram" is used for sharing moments such as photos and videos, whereas descriptive text is text that consists of description the object by factual. By using "Instagram" as learning media teachers can utilize it, so it make too easy to teach descriptive text. In addition they will more enthusiasts learning English.

Based on pre observation in Barunawati Junior High School, students have difficulties in writing skill. It is because they seldom do writing activity in class. They just write in simple sentence. Furthermore they are not master in sentence structure correctly, it makes them not confident to write paragraph. For example, students cannot write right tenses such as simple presents. Also the teacher uses old way to teach and it 
Doi: http://dx.doi.org/10.30651/tell.v7i1.2696

makes them become bored. Most of them are confused on how to start writing. They have idea in their mind, but they cannot make it into written text. Then they feel afraid to make wrong sentences, so they feel difficult to write because they are not familiar with the activity. Teachers need to have appropriate way to teach writing, so they can feel enjoy and easy to write.

Social media is used by all aged now, even though they do not have their own gadget they can borrow from parents. "Instagram" is one of social media which used capture and share the moments. According to Google Play, users can follow friends and family to see what they are up to and found others in the world that are sharing you love. It is very famous among teenagers because it makes them easy to share photos of their moments. Furthermore, people who love photography easy to share their own picture. Therefore, Instagram is very suitable to teach writing descriptive text. They can describe the picture based on the factual situation, so they are not feel bored when learn it. Also teacher can utilize social media not only for communicating or chatting but also for learning media. So, students enjoy and enthusiastic to learn it. Sometimes teacher keep use old way to teach them and it became boring. Therefore, if they have a writing assignment they disposed using google translate or copy paste from internet. It makes them have bad habit because they want to finish it instantly. Most of them abuse the use of internet. So, people should be wisely in using the internet in order to make it safe especially students and children abuse it. Therefore, people can use social media for appropriate way. One of them is learning media. By using Instagram students can see photos that shared and they can describe it by their account of Instagram. They can learn descriptive text by using new media. Furthermore, they can practice with different way.

Based on the problem above, the experiment of social media Instagram as learning media for teaching writing in descriptive text is needed. The purpose of this research is to identify the effectiveness of Teaching writing descriptive text by using social media "Instagram" to improve student's writing ability in Barunawati Junior High School.

This research aim at finding out:

1. To describe the is the effectiveness of teaching descriptive text by using social media "Instagram" to improve student's writing ability

2. To describe the student's response toward the use of social media "Instagram" to improve their writing ability

\section{Method}

Based on the purposed of the study has described by the writer in the previous chapter, research method used is quantitative method. According to Cresswell (20012:140) Quantitative research is identifies problem based on the trends to explain why something occurs, this research is focus which one variables effect the other variables. This research uses quantitative design which related with experimental design. According to Cresswell, (2002:13) one of the quantitative research characteristic is analyze the groups and relating the variables using statistical analysis. This research is including in true experiments, one of kind experimental design. According to Ary et all (2010:305) that true experimental is the subject is randomly to group and the control are provide. Experimental research typically involves two classes which experimental group and control group with receives different treatment. This research used design pretest and posttest. In this study, the writer chooses Barunawati Junior High School as the sample. In this school there are four classes for eighth grade namely VII A, VII B, VII C, and VII D. The classes VII A class as the experimental group and VII B as the control group.

In this research the population is all of the seventh grade students of SMP Barunawati in the academic year 2017/2018. Seventh grade students consist of VII A, VII B, VII C, 
and VII D. According to John and James (2006:13) said that sampling is the small part of population that is selected by the writer for observation and analysis, by using it the writer can establish the characteristic of population. To determine the number of sample of this research, the writer uses Snowball Sampling Technique. Cresswell (2012:209) stated that "snowball sampling" is a form of purposeful sampling that typically proceeds after a study begins and occurs when the researcher asks participants to recommend other individuals to be sampled. Researchers may pose this request as a question during an interview or through informal conversations with individuals at a research site". By the statement above, the writer uses it to determine the number of sample. Based on to the writer interviews English Teacher at SMP Barunawati Surabaya, Mr. Sapto. He said that VII A and VII B class is more effective to be used as sample of this study. $\mathrm{He}$ also recommended the writer to use VII A class as Control Group whereas VII B as Experimental Group. He said that two classes have same capability in learning English. Based on interview above, the writer determine that VII A will get the treatment about teaching writing descriptive text using "Instagram" as media learning, whereas VII B will not get treatment.

In this research the writer uses some instruments to do the experimental research. Pre-Test is given by the researcher before the students receive the material. According to Creswell (2012:297) that Pre-Test is a measure on some or characteristic for the participant before they receive the treatment. The first instrument is pre-test. In this research the writer give a pretest to both control and experimental group. Pretest that give about describing place and given to the VII A and VII B class with the same materials.

The second instrument is post-test. Posttest is a test that is given by the writer to both classes after experimental group receives the treatment. According to Creswell (2012:297) that a posttest use to measure for participants in an experiment after receive the treatment. In this research the teacher use the same task in pretest and posttest before.

The third instrument is questionnaires. According John and James (2006:313) Questionnaires is used on factual information is desired while the opinions rather than facts are desired then an opinionnaire or attitude scale is used.

The last instrument is rubric assessment. This research uses scoring rubric that adopted on Oshima and Hogue. It is for scoring the test of experimental class and control class.

The procedure of the research First, the researcher conduct pretest to both classes which experimental and control class. The teacher does not give the explanation of the research at first, and then the test is done. Test is intended to know the students ability in make a short paragraph of descriptive text before treatment.

Second is the implementation of treatment that is given to students. The treatment aim to know the progress of writing ability during treatment was going on. In the treatment on experimental class students, the teacher gives an explanation about descriptive text which consists of definition, generic structure, language features and exampe of Descriptive Text.

After that the teacher opens the account "Instagram" to showing the post in the profile and instruction students to make a short paragraph in comment based on the picture. Next teacher gives instruction to students open their own account then students write it.

For control class it gives explanation about descriptive text by using Power Point that well prepared. The teacher used lecturing method to teach control class. After the treatment had already been given, the both class of experimental and control is given posttest. Posttest conducts to experimental and control class. 
Warda \& Armeria, Tell : The Effectiveness of Teaching Writing...

Vol.7, No.1, 16-24, April 2019

Doi: $h$ htp://dx.doi.org/10.30651/tell.v7i1.2696

Next, the teacher and the researcher made a score for both test in experimental and control class. The result of the scoring then is compared with pretest score. So, the researcher know how far the effectiveness of using social media "Instagram" to improve students' writing ability in writing descriptive text.

\section{Findings and Discussion \\ Findings}

Based on the result, it can be concluded that the use of social media "Instagram" in teaching writing descriptive text at Barunawati Junior High School give a significant effect. It showed that experimental class students get better score than control group in descriptive text in posttest. Experimental class also get the significant different result after getting the treatment by using "Instagram" in writing descriptive text. It means that using social media "Instagram" as learning media is effective technique in teaching writing descriptive text. Indeed there is different significant of students' writing ability between both classes who taught by using "Instagram" or not.

First analysis, the researcher find out the reliability of pretest in both classes. It used to know score pretest between two raters is reliable or not, so the researcher must calculate the data. It shows that $0,900^{* *}$. The correlation between rater I and II is very strong and reliable. Next analysis is normality test in pretest. It used to know test of distributor is normal or not and from the explanation shows that test of distributor of both classes is normal because the significant is higher than $\alpha(0,05)(0,573)>\alpha(0,05)$ so it can be stated $\mathrm{H}_{0}$ is accepted and $\mathrm{H}_{1}$ is refused.

After the researcher got normality and reliability, the researcher also find the students' ability is homogeneous or not. Based on the explanation before that $p$ value is higher than $\alpha(0,05)$. It can be seen $0,237>\alpha(0,05)$. It means that $\mathrm{H} 0$ is accepted and $\mathrm{H} 1$ is refused. It shows that students' ability of both classes is homogeneous.

Next analysis is t-test calculation of pretest by using Independent Sample test. The result is the significant value of Levene's Test for Equality o Variances is 0,237> $\alpha$ $(0,05)$. So $\mathrm{H} 0$ is accepted and $\mathrm{H} 1$ is refused. It means that there is different significant between two groups. Last, it can said that students writing ability of two groups were same or equal at the beginning research.

After the researcher gave the pretest in both classes, the researcher gave the treatment in experimental class using "Instagram" in writing descriptive text. Then, researcher gave posttest to both classes. Based on the table 4.12, that mean of experimental is higher than control class. Experimental class got 85,93 and control group got 80,00. Beside the independent sample test is the sig. (2-tailed) is $0,000<0,05$ so H0 is refused and H1 is accepted. It means that mean scores of experimental and control group in posttest have the significant different with 95\% Confidence Interval of the Difference. It means that treatment that given to experimental group was successful.

Last analysis is about the effect size of experimental class by using Eta Square. It can be seen based on the result is 0,321 is larger than 0,14 so it gives large effect. It means that null hypothesis is rejected and the alternative hypothesis is accepted. So "Instagram" is effective in teaching writing descriptive text.

Finally, the researcher find out the different significant between experimental who were taught using "Instagram" had significant different effect than the control class who were not taught using "Instagram" in writing descriptive text. To conclude, that "Instagram" is effective to improving and help students'ability in writing descriptive text in Junior High School.

\section{Discussion}


Doi: http://dx.doi.org/10.30651/tell.v7i1.2696

After gave all the data, the researcher give experimental class students is Questionnaires. The purpose is to know the response of students after students got treatment by using "Instagram" in writing text at seventh grade of Barunawati Junior High School. The Questionnaires consists of ten questions (see appendix). The result can be seen below.

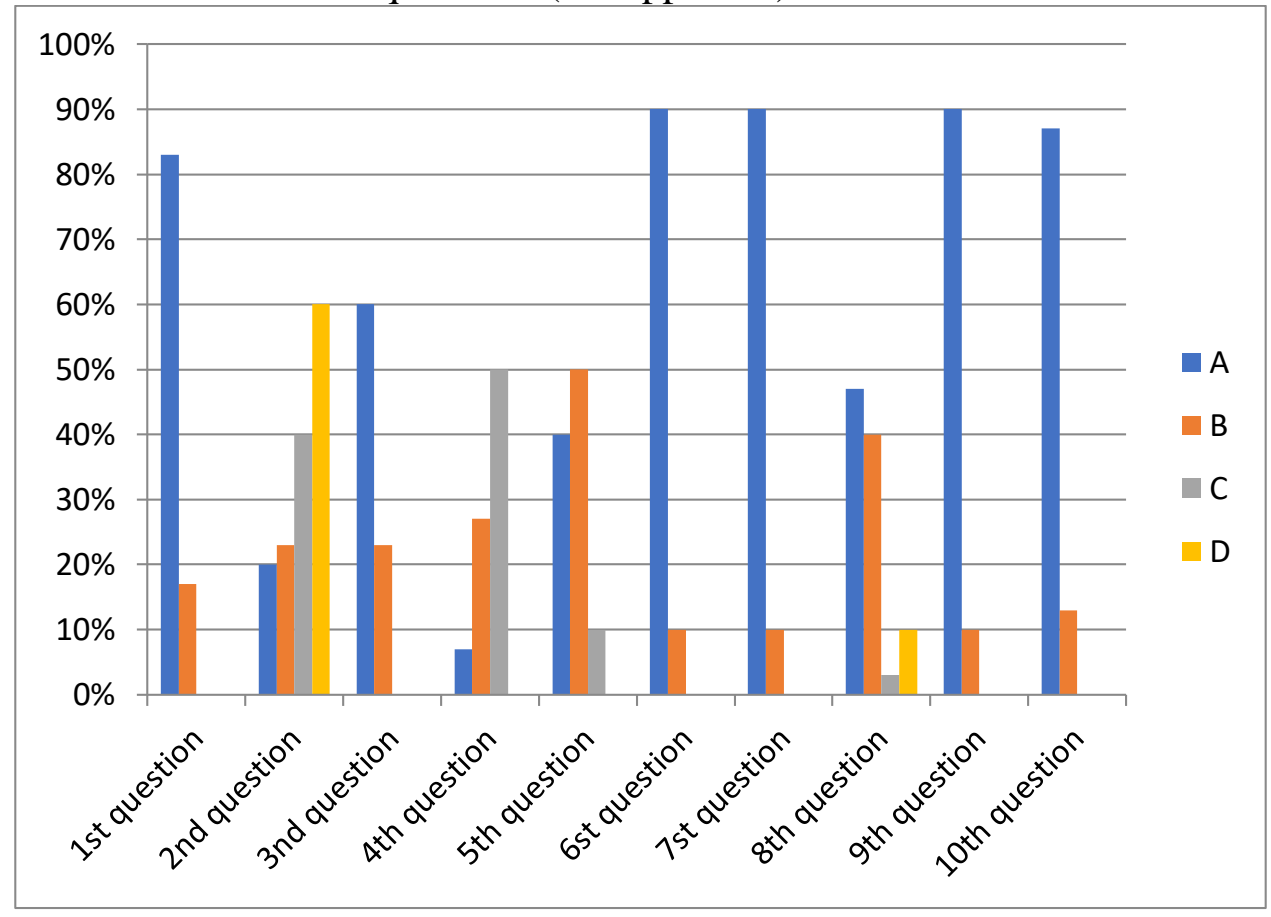

Chart 1 Percentages of Students Responses

Based on diagram above, it shows that:

In the first question, "Do you have an "Instagram" account?". There are $83 \%$ students answered A and $17 \%$ answered B. It proves that most of students have" Instagram" account.

In the second question, "What do you open the application for?". There are $20 \%$ students who answered A and 23\% students who answered B. Then $40 \%$ students answered C. It proves that students use "Instagram" as communication media.

In the third question, "How often you open your account?". There are $60 \%$ students who answered A and 23\% students answered B. It proves that students often open their account "Instagram".

In the fourth questions, "Do you understand the explanation of Descriptive Text by using "Instagram"?." There are 6\% students who answered A and there are 27\% students who answered $\mathrm{B}$ and there are $50 \%$ students who answer. It proves that students understand the explanation of descriptive text by using "Instagram".

In the fifth question, "how about you with topic that given to writing Descriptive Text using "Instagram"?." There are 40\% students who answered A and there are 50\% students who answered B. then, there are $10 \%$ students who answered C. It proves that students interest with the topic.

In the sixth question, "Is "Instagram" can help you to writing Descriptive Text easily?". There are $90 \%$ students who answered A and 10\% students who answered B. It proves that students agree that "Instagram" can help them to write descriptive text easily.

In the seventh question, "Is the social media make you easy in learning?". There are $90 \%$ students who answered A and $10 \%$ students who answered B. It proves that students can help them in learning. 
Doi: http://dx.doi.org/10.30651/tell.v7i1.2696

In eighth question, " How your opinion about the use of "Instagram" in Descriptive Text?". There are $49 \%$ students who answered A and there are $40 \%$ who answered B. Then $4 \%$ students who answered $\mathrm{C}$ and $10 \%$ students who answered D. It proves student agree that the use of "Instagram" is interesting and clearly in learning Descriptive Text.

In the ninth question, "Are you agree if "Instagram" is used in learning Descriptive Text?". There are $90 \%$ student who answered A and $10 \%$ student who answered B. It proves that students agree if learn descriptive text uses "Instagram" as media.

The last question, "Are you agree if "Instagram" is used for learning English in other skill?". There are $87 \%$ students who answered A and there are $13 \%$ students who answered B. It proves that students agree if Instagram is used for learning English in other skills.

Based on the result of students responses in the questionnaires above, it can be conclude that using "Instagram" as learning media in teaching writing descriptive text make all students interest and enjoy to learn with the media. They felt attracted because they use social media as learning media so it make them enthusiast to learn writing descriptive text. After the implementation of using "Instagram" as learning media for improve students writing ability is being motivated and increase on writing.

Furthermore the observation of the teacher was taught based on lesson plan. The teacher explained the material and the steps so clearly and gave the students during the teaching learning process. In addition, almost of the students gave good opinion in the questionnaires toward the use of "Instagram" for learning descriptive text. They were quite interested with using "Instagram" as media because they could open the social media also they learn writing English descriptive text.

The goal of using "Instagram" as media was to make all of the students enjoyable and make them easily to describe a picture with new media. Social media "Instagram" is suitable to use in teaching writing descriptive text especially for seventh grade student in Junior High School because the students should be master all of the skill especially in writing skill if they learn English. To conclude, that using social media "Instagram" as learning media in teaching writing to improve students' writing ability is useful tool to help the students being mastered on writing for seventh grade of Barunawati Junior High School Surabaya.

Based on the result, it can be concluded that the use of social media "Instagram" in teaching writing descriptive text at Barunawati Junior High School give a significant effect. It showed that experimental class students get better score than control group in descriptive text in posttest. Experimental class also gets the significant different result after getting the treatment by using "Instagram" in writing descriptive text. It means that using social media "Instagram" as learning media is effective technique in teaching writing descriptive text. Indeed there is different significant of students' writing ability between both classes who taught by using "Instagram" or not.

The researcher find out the different significant between experimental who were taught using "Instagram" had significant different effect than the control class who were not taught using "Instagram" in writing descriptive text. To conclude, that "Instagram" is effective to improving and help students'ability in writing descriptive text in Junior High School.

Based on the result of students responses in the questionnaires above, it can be conclude that using "Instagram" as learning media in teaching writing descriptive text make all students interest and enjoy to learn with the media. They felt attracted because they use social media as learning media so it make them enthusiast to learn writing descriptive text. After the implementation of using "Instagram" as learning media for improve students writing ability is being motivated and increase on writing. 
Doi: http://dx.doi.org/10.30651/tell.v7i1.2696

Furthermore the observation of the teacher was taught based on lesson plan. The teacher explained the material and the steps so clearly and gave the students during the teaching learning process. In addition, almost of the students gave good opinion in the questionnaires toward the use of "Instagram" for learning descriptive text. They were quite interested with using "Instagram" as media because they could open the social media also they learn writing English descriptive text. In addition, teacher role as reminder for students of the use "Instagram" as learning media is important. Teacher asked them to do their practice to know the students' writing ability is raising, so teacher should encourage students to keep practice writing descriptive text by "Instagram".

The goal of using "Instagram" as media was to make all of the students enjoyable and make them easily to describe a picture with new media. Social media "Instagram" is suitable to use in teaching writing descriptive text especially for seventh grade student in Junior High School because the students should be master all of the skill especially in writing skill if they learn English. To conclude, that using social media "Instagram" as learning media in teaching writing to improve students' writing ability is useful tool to help the students being mastered on writing for seventh grade of Barunawati Junior High School Surabaya.

\section{Conclusion}

Based on the result and discussion in previous chapter, it could be concluded that the use of social media "Instagram" in teaching writing descriptive text to improve students' ability was effective. It was proved by obtained score of

It means that $\mathrm{H}_{0}$ was rejected and $\mathrm{H}_{1}$ was accepted. Then the conclusion is there was a significance difference in the achievement between students in class VII A who were taught by using social media "Instagram" and students is class VIIB who were taught without social media "Instagram". The average score of experimental class was 85,93 and the average score of control class was 80,00 . It means that experimental class which VII A was better than the control class which VII B.

The experimental class students are more enthusiast and interest in learning process because the teacher used social media "Instagram" as learning media. After using social media "Instagram" as learning media, students can understand the explanation of Descriptive Text. They can make a short paragraph of descriptive text grammatically and arrange correctly. 
Warda \& Armeria, Tell : The Effectiveness of Teaching Writing...

Vol.7, No.1, 16-24, April 2019

Doi: http://dx.doi.org/10.30651/tell.v7i1.2696

\section{REFERENCES}

Ary. D., Jacobs, L. C., Sorensen, C., \& Razavieh, A. 2010. Introduction to Research in Education eighth edition. Canada: Wadsworth Cengage Learning.

Best, John W. and Kahn, James V. 2006. Research in Education: United States of America.

Creswell, Jhon W. 2012. Educational Research Planning, conducting, and evaluating Quantitative and Qualitative research. Fourth Edition. Boston: Pearson Education, Inc.

Brown, H Douglas. 2001. Language Assessment Principles and Classroom Practices. San Francisco: Pearson Longman.

Heaton, J.B. 1975. Writing English Language Test. New York: Longman, Inc.

Harmer, Jeremy. 2004. How to Teach Writing: Pearson Education Limited.

Hyland, Ken. 2003. Second Language Writing. New York: Cambridge University Press.

Hedge. Tricia. 2005. Writing Second Edition: Oxford University.

Nunan, David. 2005. Practical English Language Teaching Young Learners. New York: Mc-Graw Hill.

Oshima, Alice \& Ann Hogue. 2007. Writing Academic English. Fourth Edition. United State of America: Pearson Longman

Parker, Jessica K. 2010.Teaching Teach Savvy Kids. Bringing Digital Media Into The Classroom, Grades 5-12. United States of America

Rao, Bolla Mallikharjuna. 2014. Use of Media as an Instructional Tool in English Language Teaching (ELT) at Undergraduate Level. Insternational Journal of English and Literature. Vol. 5 (6): pp. 141-143.

Rochman, Encik Adhiva \& Iskandar, Budi Permadi. 2015. Users' Engagement Toward the Brand Accounts in Instagram Based on the AISAS Model. Journal of Business and Mangement. Vol. no 4. Pp: 890-900

Taprial, V. and Kanwar P. 2012. Understanding Social Media. 